\title{
ANALISIS KETERAMPILAN BERPIKIR KREATIF SISWA SMA DALAM MEMECAHKAN MASALAH FISIKA
}

\author{
Hisdamayanti Djupanda, Yusuf Kendek dan I Wayan Darmadi \\ hisdamayanti45@gmail.com \\ Program Studi Pendidikan Fisika FKIP Universitas Tadulako \\ Jl. Soekarno Hatta Km. 9 Kampus Bumi Tadulako Tondo Palu - Sulawesi Tengah
}

\begin{abstract}
Penelitian ini bertujuan untuk mendeskripsikan keterampilan berpikir kreatif siswa dalam memecahkan masalah fisika. Jenis penelitian yang digunakan adalah deskriptif-kualitatif. Subyek penelitian ini terdiri dari 30 siswa Kelas XI MIA 5 SMA N 4 Palu. Data diperoleh melalui tes berpikir kreatif, tes pemecahan masalah dan wawancara. Tes berpikir kreatif terdiri dari 8 butir pertanyaan yang telah divalidasi oleh ahli. Tes pemecahan masalah terdiri atas 5 butir yang dikerjakan responden dan diikuti dengan wawancara. Hasil penelitian menunjukkan bahwa masing-masing aspek berpikir kreatif punya cara yang berbeda dalam memecahkan masalah fisika, khusus aspek elaborasi responden menunjukkan hasil yang lebih baik dalam memecahkan masalah dibandingkan aspek berpikir kreatif yang lainnya.
\end{abstract}

Kata Kunci : Keterampilan, Berpikir Kreatif, Pemecahan Masalah Fisika

\section{PENDAHULUAN}

Kemampuan untuk memecahkan masalah menjadi salah satu fokus yang ingin dicapai oleh guru, sebab melalui kemampuan pemecahan masalah para siswa dapat mengaktualisasikan apa yang mereka dapatkan dari pembelajaran untuk kemudian diterapkan dalam kehidupan mereka. Kemampuan seseorang dapat memecahkan masalah fisika dengan baik pada dasarnya merupakan tujuan utama dari proses pendidikan, melalui kemampuan pemecahan masalah, hasil belajar setiap siswa diharapkan menjadi lebih bermakna, serta hasil dari proses pembelajaran tersebut dapat bermanfaat bagi siswa $[1]$,

Setiap siswa memiliki pemikiran yang berbeda-beda dalam menyelesaikan masalah. $\mathrm{Hal}$ ini juga mempengaruhi bagaimana siswa menyelesaikan permasalahan. Keterampilan berpikir kreatif adalah keterampilan kognitif untuk memunculkan dan mengembangkan gagasan baru, ide baru sebagai pengembangan dari ide yang telah lahir sebelumnya dan keterampilan untuk memecahkan masalah secara divergen (dari berbagai sudut pandang) [2].

Pentingnya mengembangkan kreativitas siswa dan kemampuan berpikir kreatif melalui aktivitas-aktivitas kreatif dalam pembelajaran. Salah satu cara yang dapat dilakukan adalah dengan pemecahan masalah tipe what's another way. Hasil penelitiannya menunjukkan bahwa kemampuan pemecahan masalah siswa SMP Negeri 2 Sidoarjo baik, dengan persentase sebesar $52,5 \%$ dan kemampuan berpikir kreatif siswa meningkat [3].

Berdasarkan uraian di atas, keempat aspek berpikir kreatif tersebut perlu dianalisis. Ciri non kognitif termasuk ciri berpikir kreatif, yaitu motivasi, sikap dan kepribadian kreatif. Dan dalam ciri kognitif termasuk ciri berpikir kreatif, yaitu orisinalitis, fleksibilitas, kelancaran dan elaborasi $_{[4]}$. Penelitian ini menggunakan tes berpikir kreatif dengan menganalisis keempat aspek tersebut sebagai indikator untuk mengetahui cara siswa dalam memecahkan masalah fisika serta memberikan tes akhir yaitu tes pemecahan masalah untuk mendeskripsikan kemampuan siswa dalam memecahkan masalah fisika berdasarkan keempat aspek keterampilan berpikir kreatif

Sejalan dengan uraian di atas dan mengingat pentingnya keterampilan berpikir kreatif siswa sebagai upaya peningkatan kemampuan pemecahan masalah fisika, peneliti merasa perlu mengetahui tingkat keterampilan berpikir kreatif siswa dalam memecahkan masalah fisika

\section{METODE PENELITIAN}

Jenis penelitian ini merupakan penelitian Deskriptif-kualitatif. Subyek dalam penelitian ini adalah 30 siswa-siswi Kelas XI Semester I di SMA N 4 Palu Tahun Ajaran 2014/2015 untuk tes awal keterampilan berpikir kreatif. Dalam penelitian ini sebanyak 8 responden diambil Pemilihan delapan berdasarkan skor tertinggi siswa dalam masing-masing aspek keterampilan berpikir kreatif yaitu 2 responden dengan skor tertinggi pada kefasihan, 2 responden dengan skor tertinggi pada aspek kebaruan, 2 skor 
tertinggi pada aspek keluwesan, dan 2 responden tertinggi pada aspek elaborasi.

Tahap penyajian data dalam penelitian meliputi:

1. Menyajikan tabel pengelompokkan hasil jawaban tes pemilihan responden siswa, yang digunakan untuk menentukan responden penelitian.

2. Menyajikan hasil pekerjaan Tes pemecahan masalah responden .

3. Menyajikan hasil wawancara yang telah dicatat melalui panduan wawancara.

Hasil penyajian data yang berupa pekerjaan siswa dan hasil wawancara dilakukan analisis, kemudian disimpulkan yang berupa data temuan sehingga mampu mendeskripsikan permasalahan dalam penelitian ini.

Data kemampuan berpikir kreatif yang diperoleh kemudian diolah untuk mengetahui persentase jumlah siswa yang memunculkan indikator kemampuan berpikir kreatif dengan rumus:

$$
\begin{aligned}
& X=\frac{\text { Jumlah siswa yang memiliki ciri berpikir kreatif }}{\text { jumlah siswa }} \times 100 \% \\
& \text { keterangan: } \\
& \mathrm{X}=\text { persentase keterampilan berpikir } \\
& \text { kreatif }
\end{aligned}
$$

\section{HASIL DAN PEMBAHASAN}

30 responden dalam satu kelas menunjukkan nilai rata-rata setiap aspek diantaranya :

1. Aspek Kelancaran : $69 \%$

2. Aspek Keluwesan : $76 \%$

3. Aspek Kebaruan : $: 70 \%$

4. Aspek Elaborasi : $50 \%$

Secara kesuluruhan untuk tingkat keterampilan berpikir kreatif siswa, masih berada pada kategori rendah untuk aspek Elaborasi dan aspek Kelancaran. Hasil rata-rata per aspek di atas diambil dari 30 responden. Tingkat berpikir kreatif aspek keluwesan memiliki capaian persen yang paling tinggi, dan aspek elaborasi memiliki capaian persen terendah. Namun, dalam hal ini setiap siswa memiliki tingkat berpikir kreatif yang berbedabeda

Penelitian tersebut ini terlihat perbedaan masing-masing aspek dalam memecahkan masalah fisika. Berikut tabel 3.1 Hasil Tabulasi Tes Pemecahan Masalah Fisika.

Tabel 1 Hasil Tabulasi Tes Pemecahan Masalah

\begin{tabular}{|c|c|c|c|}
\hline No. & $\begin{array}{c}\text { Inisial } \\
\text { Responden }\end{array}$ & Aspek & skor \\
\hline 1 & RK-4 & Keluwesan & 28 \\
\hline 2 & RK-26 & Keluwesan & 21 \\
\hline
\end{tabular}

\begin{tabular}{|l|c|c|c|}
\hline 3 & RK-7 & Orisinalitas & 23 \\
\hline 4 & RK-29 & Orisinalitas & 10 \\
\hline 5 & RK-14 & Elaborasi & 35 \\
\hline 6 & RK-11 & Elaborasi & 41 \\
\hline 7 & RK-17 & Kelancaran & 30 \\
\hline 8 & RK-22 & Kelancaran & 30 \\
\hline
\end{tabular}

Hasil data tabulasi di atas, terlihat perbedaan skor yang di peroleh oleh masing-masing aspek keterampilan berpikir kreatif siswa dalam memecahkan masalah fisika. Aspek elaborasi menunjukkan hasil skor yang lebih tinggi dibandingkan aspek yang lain seperti yang ditunjukkan pada tabel di atas.

\section{1) Kelancaran Terhadap \\ Masalah Fisika \\ Pemecahan}

Responden RK-22 yang memiliki keterampilan berpikir kreatif aspek kelancaran ini dalam memecahkan masalah fisika mendapatkan skor 30. Ini menunjukkan bahwa kemampuan memecahkan masalah fisikanya masih kurang. Aspek kelancaran pada dasarnya hanya mengandalkan kemampuan seseorang dalam menjawab soal dengan banyak jawaban. Berikut ini transkip jawaban RK-22 dalam memecahkan masalah fisika.

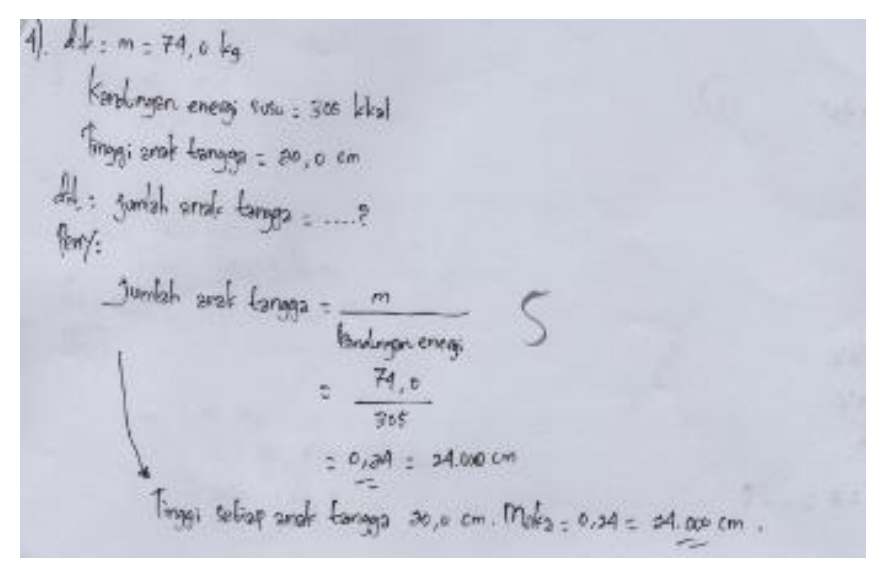

Gambar 1. Jawaban Soal Nomor 4, Responden RK-22

Peneliti : Pada soal nomor satu, konsep apa yang anda ketahui?

Rk-22 : konsep tentang kalor

Peneliti : anda mengerti atau tidak dengan soal ini?

RK-22 : tidak mengerti, nanti dibaca berulang kali baru paham sedikit-sedikit lah tapi saya lupa rumusnya.

Peneliti : apa yang anda dikerjakan?

RK-22 : karena saya tidak paham, jadi saya cuma jawab diketahui, ditanya, tapi jawabannya mengarang.

Peneliti : Untuk soal nomor dua bagaimana?

RK-22 : gampang, saya jawab. 
Peneliti : pada soal nomor dua, menurut anda membahas tentang konsep apa?

RK-22 : jadi menurut saya maksud dari soal tersebut yaitu suhu khairul dari skala derajat celsius diubah ke skala reamur.

Peneliti : untuk soal nomor 3 bisa dijelaskan maksudnya?

RK-22 : nomor 3 ini sempat bingung karena tidak tahu rumusnya jadi saya cuma hitung-hitung biasa saja, saya juga tidak mengerti soalnya susah saya menganalisa.

Peneliti : soal nomor 4 bisa dikerja?

RK-22 : saya tidak pernah mendapat rumus dan mempelajari tentang soal ini sebelumnya, sehingga belum tahu cara pengerjaannya

Peneliti : Jika diberikan rumus, apakah bisa dikerjakan?

RK-22 : bisa

Peneliti : soal nomor 5 ini apa yang ditanyakan?

RK-22 : Tentang pemuaian, jadi yang ditanyakan tentang panjang jembatan setelah diberikan suhu sekian

Peneliti : Bisa jelaskan cara pengerjaannya?

RK-22 : saya tidak ingat juga rumusnya.

Dari hasil jawaban dan wawancara responden RK-22 terlihat bahwa kemampuan responden dalam memecahkan masalah fisika adalah lebih banyak mencoba untuk menjawab tanpa memikirkan jawaban benar atau salah. Untuk dapat memecahkan masalah dengan perencanaan penyelesaian permasalahan yang matang, maka diperlukan keterampilan dan pemahaman tentang berbagai strategi pemecahan masalah. RK-22 sudah mencoba menjawab permasalahan dari soal yang diberikan walaupun tidak tepat. Olehnya itu gambaran ide atau kelancaran dalam berpikir adalah salah satu cara yang baik dalam menyelesaikan masalah meski terkadang seringkali kurang tepat. Jika dilihat dari kemampuan berpikir kreatif RK-22 pada tes berpikir kreatif aspek kelancaran berpikir cukup tinggi, sehingga hasilnya dalam mememcahkan masalah fisika signifikan, yaitu mencoba menjawab dengan berbagai strategi pula.

\section{Aspek Keluwesan Terhadap Pemecahan Masalah Fisika.}

Responden yang memiliki aspek keluwesan kategori tinggi dalam memecahkan masalah fisika memiliki skor hampir sama dengan aspek kelancaran, walaupun masih sedikit lebih di bawah. Orang-orang yang memiliki tingkat berpikir keluwesan yang tinggi memiliki kesulitan dalam mengolah permasalahan dengan baik, sebab pada dasarnya orang-orang dalam kategori ini akan mencari jawaban yang tidak menyulitkan dirinya sendiri. Hal ini ditujukkan pada jawaban Responden $\mathrm{Rk}-4$

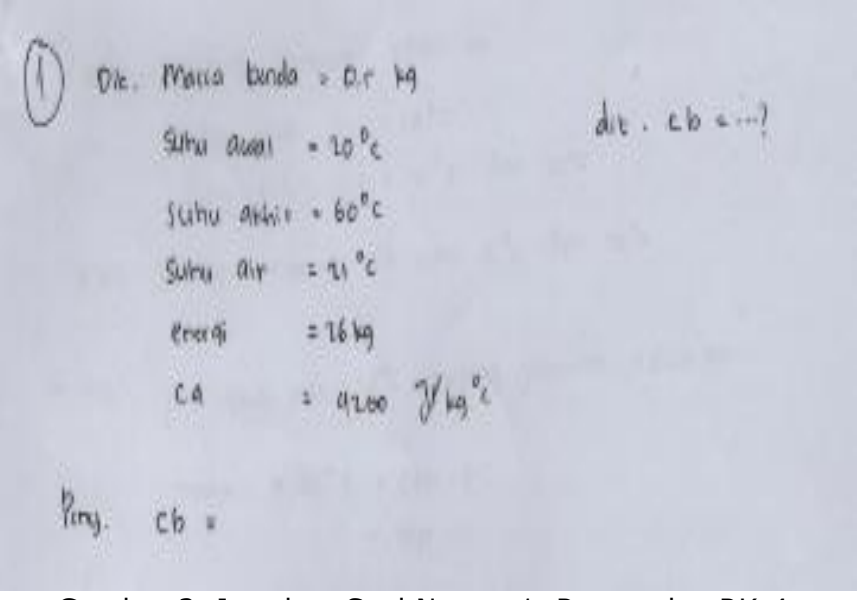

Gambar 2. Jawaban Soal Nomor 1, Responden RK-4

Dari jawaban responden di atas menunjukkanbahwa responden belum baik dalam memecahkan masalah fisika, responden lebih memilih untuk tidak menjawab pertanyaan, dibandingkan menjawab tetapi salah

\section{Aspek Orisinalitas Terhadap Pemecahan Masalah Fisika}

Dalam memecahkan masalah fisika responden yang memiliki kategori tinggi dalam aspek orisinalitas, menggunakan cara yang berbeda dalam menyelesaikan masalahnya. Responden yang memiliki kemampuan berpikir kreatif aspek orisinalitas memperoleh skor 20 untuk RK-7 dan skor 10 untuk RK-29. Sedikit lebih tinggi dibandingkan dengan responden pada aspek kelancaran dan keluwesan.

Responden RK-7 lebih memilih banyak diam ketika di wawancarai. Responden memperjelas bahwa benar-benar tidak tahu. Berikut hasil wawancara penilit bersama responden

Peneliti : ada beberapa soal tidak dijawab, kenapa?

Rk-7 : saya tidak tahu, saya tidak mau sama dengan yang lain, sehingga saya punya yang unik ada yang saya isi mengarang, ada yang saya kosongkan

Peneliti : Apakah itu benar-benar tidak tahu, sehingga ada tulisan "kaka saya tidak tau jawabnnya, maaf kaka ee "

Rk-7 : iya. Saya paham maksud soal tersebuttanya paham atau tidak, tapi saya tidak bisa kerja

\section{Aspek Elaborasi Terhadap Pemecahan Masalah Fisika}


Seseorang yang memiliki kemampuan berpikir aspek elaborasi yang baik, cenderung menyelesaikan masalah dengan sistematis dan beruntun, lebih detail, dan penuh dengan penjelasan. Masalah fisika yang peneliti sajikan dalam skripsi ini menuntut responden untuk mampu menjawab masalah dengan sistematis, jelas. dan baik dalam penjelasannya. Hal ini ternyata selaras, meski jawaban responden tidak benar seluruhnya, tetapi termasuk unggul diantara ketiga aspek berpikir kreatif yang lain. Transkip jawaban dengan skor yang lebih tinggi dari yang lain ada pada responden $\mathrm{RK}-4$ dengan skor 43 dan RK-14 dengan skor 44 . Berikut transkip jawaban RK-4

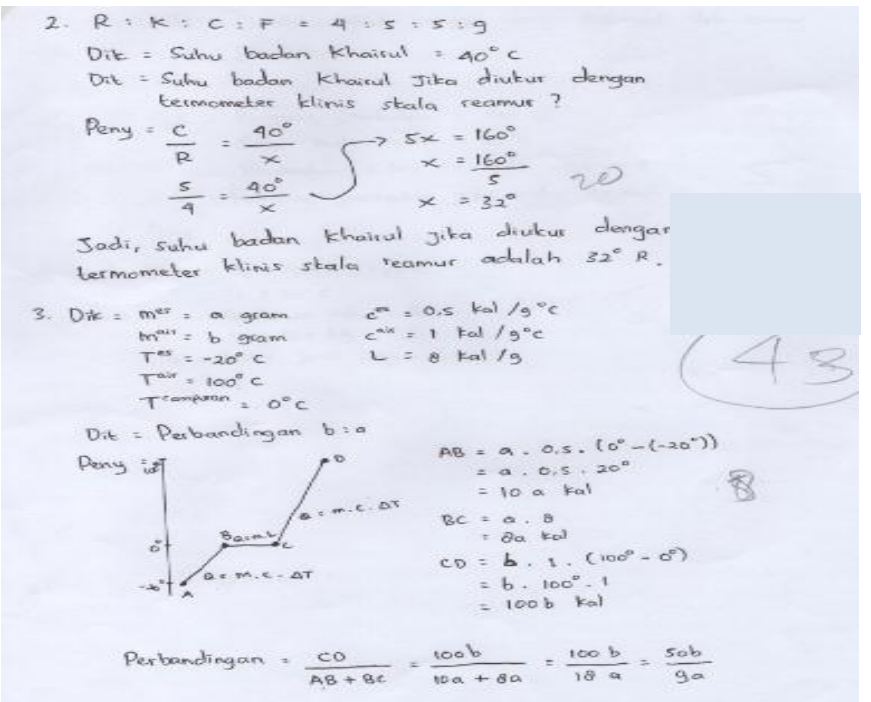

Gambar 3. Jawaban Soal Nomor 2 dan 3, Responden RK-4

\section{Analisis Pengaruh antara Keterampilan Berpikir Kreatif Dalam Memecahkan Masalah Fisika}

Hasil analisis penskoran pemecahan masalah dapat dilihat pada tabel berikut :

Tabel 6.1 Analisis penskoran tes pemecahan masalah

\begin{tabular}{|l|l|l|c|c|c|c|c|c|}
\hline \multirow{2}{*}{ No } & \multirow{2}{*}{ Responden } & \multirow{3}{*}{ Aspek } & \multicolumn{5}{|c|}{ Skor per butir soal (skor ideal per } \\
\cline { 4 - 9 } & & & $\mathbf{1}$ & $\mathbf{2}$ & $\mathbf{3}$ & $\mathbf{4}$ & $\mathbf{5}$ & Jumlah \\
& & $(\mathbf{2 0})$ & $(\mathbf{1 0})$ & $(\mathbf{2 5})$ & $(\mathbf{2 5})$ & $(\mathbf{2 0})$ & $(\mathbf{1 0 0})$ \\
\hline 1. & RK-4 & Keluwesan & $\mathbf{5}$ & $\mathbf{3}$ & $\mathbf{5}$ & $\mathbf{5}$ & $\mathbf{1 0}$ & $\mathbf{2 8}$ \\
\hline 2. & RK-26 & Keluwesan & $\mathbf{5}$ & $\mathbf{1 0}$ & $\mathbf{1}$ & $\mathbf{1 0}$ & $\mathbf{5}$ & $\mathbf{3 1}$ \\
\hline 3. & RK-7 & Orisinalitas & $\mathbf{5}$ & $\mathbf{3}$ & $\mathbf{5}$ & $\mathbf{5}$ & $\mathbf{5}$ & $\mathbf{2 3}$ \\
\hline 4. & RK-29 & Orisinalitas & $\mathbf{0}$ & $\mathbf{3}$ & $\mathbf{1 0}$ & $\mathbf{0}$ & $\mathbf{0}$ & $\mathbf{1 3}$ \\
\hline 5. & RK-14 & Elaborasi & $\mathbf{5}$ & $\mathbf{1 0}$ & $\mathbf{1 0}$ & $\mathbf{5}$ & $\mathbf{5}$ & $\mathbf{3 5}$ \\
\hline 6. & RK-11 & Elaborasi & $\mathbf{1 0}$ & $\mathbf{3}$ & $\mathbf{1 0}$ & $\mathbf{0}$ & $\mathbf{1 0}$ & $\mathbf{4 1}$ \\
\hline 7. & RK-17 & Kelancaran & $\mathbf{5}$ & $\mathbf{1 0}$ & $\mathbf{5}$ & $\mathbf{5}$ & $\mathbf{5}$ & $\mathbf{3 0}$ \\
\hline 8. & RK-22 & Kelancaran & $\mathbf{0}$ & $\mathbf{1 0}$ & $\mathbf{5}$ & $\mathbf{5}$ & $\mathbf{1 0}$ & $\mathbf{3 0}$ \\
\hline
\end{tabular}

Tabel 6.1 terlihat bahwa masing-masing aspek memiliki kemampuan yang berbeda-beda untuk memecahkan masalah pada setiap butir soal. RK-4 (keluwesan) belum mampu memecahkan masalah fisika dengan baik. Namun, dari analisis jawabannya RK-4 mampu memahami maksud soal yang diberikan oleh peneliti. Soal nomor 1, 3, dan 4 responden hanya mampu menjawab maksud soal yaitu menjabarkan apa yang diketahui dan tanyakan dari soal. Pada soal nomor 3 dan 10 responden menjabarkan apa yang diketahui dan yang ditanyakan, serta menyelesaikan soal. Namun penyelesaian dan rumus yang digunakan belum tepat. Seseorang yang memiliki kemampuan berpikir kreatif aspek keluwesan mampu menjabarkan dan memahami suatu permasalahan, seringkali mencari cara atau strategi yang lebih mudah dan tidak sulit, ini terlihat pada responden RK-4 yang menjawab soal dengan cara yang sangat singkat tetapi belum tepat.

Responden RK-26 memiliki kemampuan yang hampir sama dengan RK-4 yaitu memahami maksud dari tes pemecahan masalah yang dikerjakan namun, belum mampu memecahkan masalah dengan baik. Jawaban responden RK26 pada soal nomor 1,3 dan 5 hanya mampu menguraikan apa yang diketahui dan ditanyakan, sedangkan dalam penyelesaiannya responden ini mengosongkan jawabannya. Hal ini dikarenakan responden tidak mengetahui cara penyelesaiannya.

Responden RK-7 memiliki keterampilan berpikir kreatif aspek orisinalitas (kebaruan). Seseorang yang memiliki keterampilan berpikir aspek orisinalitas seringkali ingin terlihat beda dengan orang lain, menciptakan ide baru yang tidak biasa dilakukan leh orang lain (unik). Hal yang selaras terlihat dari jawaban responden ini menjawab tes pemecahan masalah dengan cara yang tidak biasanya, mencari jalan keluar sendiri yang lebih sederhana tetapi menunjukkan kesalahan secara keseluruhan, jawaban pada soal nomor 1, 3, 4 dan 5 hanya di selesaikan dengan penjabaran apa yang diketahui dan dijawab. Sementara jawaban pada 
soal nomor 2 dijawab dengan cara mengarang rumus yang menyebabkan jawaban salah. Menunjukkan responden ini belum mampu memecahkan masalah dengan baik.

Responden RK-29 yang memiliki keterampilan berpikir aspek orisinalitas ini lebih memilih mengosongkan jawaban nomor 1, 4, dan 5 . Sedangkan untuk jawaban nomor 2 dan 3 responden mencoba menjawab dengan cara yang tidak pernah dituliskan pada buku atau pun rumus lainnya. Hasil wawancara responden mengaku tidak mengerti dengan maksud beberapa soal dan merasa tidak mampu menyelesaikannya sehingga responden lebih memilih untuk menjawab sembarangan.

Pada aspek elaborasi terdapat perbedaan yang cukup signifikan dibandingkan aspek lainnya. Seseorang yang memiliki keterampilan berpikir kreatif aspek elaborasi yang baik akan mampu memecahkan masalah secara sistematis, runtut dan koheren. Definisi dari aspek tersebut ditunjukkan pada responden RK14 yang menjawab pertanyaan dengan runtut pada soal nomor 2 dan 3 meskipun rumus yang digunakan kurang tepat. Namun dalam lampiran 10 dapat dilihat responden ini menjabarkan jawaban dengan lengkap. Sementara jawaban soal nomor 1,4 ,dan 5 responden memilih hanya menjawab apa yang diketahu dan ditanyakan hal ini disebabkan responden belum belum pernah diajarkan soal model seperti itu ketika duduk di bangku kelas 1 .

Responden yang memiliki keterampilan berpikir kreatif aspek elaborasi yang lain pada RK-11 menunjukkan adanya kemampuan menjabarkan jawaban lebih sistematis dan koheren. Dapat dilihat pada skor jawaban nomor 1, 3 dan 5. Responden ini mampu memecahkan masalah pada soal nomor 1 , jawaban di uraikan dengan runtut namun hasil akhirnya masih menunjukkan kekeliruan.

Responden yang memiliki keterampilan baik pada aspek kelancaran memiliki kemampuan menjawab soal dengan berbagai cara atau menjawab semua pertanyaan tanpa memandang jawaban mereka benar atau salah. Hal ini ditunjukkan pada responden RK-17 dan RK-22, kedua responden ini menjawab seluruh pertanyaan yang diberikan pada tes pemecahan masalah dengan lancar, meskipun jawaban pada lembar jawaban masih banyak kekeliriuan dalam penyelesaiannya.
Hasil yang telah diuraikan di atas adalah 8 responden yang diberikan tes pemecahan masalah masing-masing aspek sebanyak 2 orang dengan skor tertinggi. Skor tes pemecahan masalah yang diperoleh : RK-17 aspek kelancaran $=30$, RK-22 aspek kelancaran $=30, \mathrm{RK}-4$ aspek Fleksibilitas $=28, \mathrm{RK}-26$ aspek Fleksibilitas $=30, \mathrm{RK}-7$ aspek kebaruan $=$ 21, RK-29 aspek Kebaruan $=10, \mathrm{RK}-14, \mathrm{RK}-11$ aspek elaborasi $=41$, dan RK-14 aspek elaborasi $=35$.

Khusus masalah fisika, hasil tes pemecahan masalah yang dilakukan untuk melihat perbedaan masing-masing aspek dalam memecahkan masalah fisika menunjukkan adanya perbedaan yang cukup signifikan. 2 responden dengan skor tertinggi pada aspek elaborasi memiliki skor yang lebih baik dibandingkan aspek berpikir kreatif lainnya. Hal ini dikarenakan aspek elaborasi memiliki kemampuan menjelaskan secara terperinci, runtut dan koheren terhadap prosedur, jawaban atau situasi tertentu. Tes pemecahan masalah yang diberikan memuat masalah matematis fisika, sehingga teori yang ada cukup membuktikan siswa yang memiliki aspek elaborasi tinggi lebih mampu memecahkan masalah fisika jenis ini. Meskipun dari hasil wawancara didapatkan faktor lain yang mempengaruhi responden memecahkan masalah misalnya belum belajar, lupa rumus, kurang sehat dan faktor lainnya.

\section{Kesimpulan}

Siswa yang memiliki keterampilan berpikir aspek elaborasi mampu memecahkan masalah fisika lebih baik daripada siswa yang memiliki keterampilan berpikir kreatif pada aspek keluwesan, orisinalitas, dan kelancaran. Hasil penelitian menunjukkan skor yang diperoleh aspek elaborasi pada tes pemecahan masalah lebih tinggi dibandingkan ketiga aspek lainnya, berikut perolehan skornya : RK-17 aspek kelancaran $=30$, RK-22 aspek kelancaran $=30$, RK-4 aspek Fleksibilitas $=28$, RK-26 aspek Fleksibilitas $=30$, RK-7 aspek kebaruan $=21$, RK-29 aspek Kebaruan $=10$, RK-14, RK-11 aspek elaborasi $=41$, dan RK-14 aspek elaborasi $=35$.

\section{Saran}


Berdasarkan kesimpulan di atas maka saran yang dapat diberikan pada penelitian ini adalah:

1. Guru perlu menekankan pentingnya mengasah keterampilan berpikir kreatif siswa.

2. Untuk penelitian selanjutnya kiranya dapat melakukan penelitian sejenis dengan materi dan lokasi penelitian yang berbeda. Perbedaan materi dan lingkungan mungkin akan menimbulkan karakterisitk keterampilan berpikir siswa dalam memecahkan masalah fisika.

3. Untuk penelitian selanjutnya kiranya dapat menyeragamkan poin pada setiap rubrik soal tes berpikir kreatif untuk memudahkan penilaian pada penelitian ini.

4. Untuk penelitian selanjutnya kiranya dapat menggunakan panduan skripsi khusus analisis sebagai pertimbangan agar ada standarisasi yang lebih jelas dalam penyusunan skripsi jenis Deskripsi-kualitatif.

\section{DAFTAR PUSTAKA}

[1] Amalia, S. (2011). Analisis Kemampuan Pemecahan Masalah Matematis Siswa SMA. Skripsi pada FM IKIP Bandung: tidak diterbitkan

[2] Saehana, Lusiana.(2013).Perbandingan Keterampilan Berpikir Kritis dan Kreatif siswa pada Pembelajaran ELearning Dengan Pembelajaran Konvensional di kelas $x$ SMA N 2 Palu.Tesis Sarjana Pada Pendidikan Sains Palu.Tidak Diterbitkan

[3 Efendi Agus. 2005. Revolusi Kecerdasan Abad 21. Bandung: Alfabeta

[4] Tatag, dkk.2006.Meningkatkan Kemampuan Berpikir Kreatif siswa Melalui Pemecahan Masalah Tipe "Whats Another Way".Universitas Negeri Surabaya: Mojokerto 